удк 657.1

DOI https://doi.org/10.32851/2708-0366/2020.4.22

Скрипник М.I.

доктор економічних наук, профресор, завідувач кафедри обліку і аудиту,

Київський національний університет технологій та дизайну

ORCID: https://orcid.org/0000-0002-6205-0754

Григоревська О.O.

кандидат економічних наук, доцент, доцент кафредри обліку і аудиту,

Київський національний університет технологій та дизайну ORCID: https://orcid.org/0000-0001-8279-3523

Skrypnyk Margarita, Hryhorevska Olena Kyiv National University of Technology and Design

\title{
ОБЛІКОВО-АНАЛІТИЧНЕ ЗАБЕЗПЕЧЕННЯ ВИРОБНИЦТВА ОРГАНІЧНОЇ ПРОДУКЦІЇ
}

\section{ACCOUNTING AND ANALYTICAL SUPPORT FOR THE PRODUCTION OF ORGANIC PRODUCTS}

Мета статті полягає в оцінюванні наявних підходів до обліково-аналітичного забезпечення виробництва органічної продукції та спробі їх уніфікацї̈ для формування ефективного облікового-аналітичного забезпечення. Проведені дослідження дали змогу актуалізувати важливість наукового пошуку у сфері розроблення обліково-аналітичного забезпечення виробництва органічної продукиіі. На основі проаналізованих матеріалів запропоновано власний підхід до обліково-аналітичного забезпечення виробниитва органічної продукиії, щчо формується під впливом організачійних особливостей суб'єкта господарювання (розмір підприємства, вплив організаційної структури, структура управління виробничим процесом, технологія виробництва, внутрімні стандарти діяльності, кваліфікація персоналу) та особливостей галузі функціонування (сочіальна значимість виготовленої продукиії, недовготривалий виробничий цикл, відсутність незавершеного виробництва, ииклічність продажу, суворе дотримання технологій та норм витрат матеріалів, близькість до ринків збуту готової продукції). Обгрунтовано, що обліково-аналітичне забезпечення формусться з контрольної підсистеми, облікової підсистеми та аналітичної підсистеми. Деталізовано складові частини обліково-аналітичного забезпечення щодо інформаційного забезпечення та управління витратами на виробництво органічної продукиії.

Ключові слова: органічна продукиія, органічне виробництво, обліково-аналітичне забезпечення, витрати, звітність.

Цель статьи заключается в оиенивании существуюших подходов к учетно-аналитическому обеспечению производства органической продукции и попытке их унификации для формирования эффективного учетно-аналитического обеспечения. Проведенные исследования позволили актуализировать важность научного поиска в сфере разработки учетно-аналитического обеспечения производства органической продукиии. На основе проанализированных материалов предложен собственный подход к учетно-аналитическому обеспечению производства органической продукиии, который формируется под влиянием организационных особенностей субъекта хозяйствования (размер предприятия, влияние организационной структуры, структура управления производственным процессом, технология производства, внутренние стандарть деятельности, квалификация персонала) и особенностей отрасли функиионирования (социальная значимость изготовленной продукиии, недлительньий производственный иикл, отсутствие незавершенного производства, иикличность продажи, строгое соблюдение технологий и норм расходов материалов, близость к рынкам сбыта готовой продукиии). Обосновано, что учетно-аналитическое обеспечение форми- 
руется из контрольной подсистемь, учетной подсистемь и аналитической подсистемы. Детализированы составляющие учетно-аналитического обеспечения касательно информацุионного обеспечения и управления затратами на производство органической продукции.

Ключевые слова: органическая продукция, органическое прочзводство, учетно-аналитическое обеспечение, расходы, отчетность.

The purpose of the article is to evaluate the existing approaches to accounting and analytical support of organic production and try to unify them to form an effective accounting and analytical support. In the process of research the methods of observation, comparison, analysis, synthesis, and generalization were used. The study is based on the hypothesis that high-quality accounting and analytical support will increase the validity, efficiency and analytical information about the production of organic products to determine the impact of such operations on business activities in accordance with modern management requirements, strengthen the responsibility of performers, and improve management accounting. The conducted researches allowed actualizing the importance of scientific research in the field of development of accounting and analytical support of organic production. Based on the analyzed materials, our own approach to accounting and analytical support of organic production, which is formed under the influence of organizational characteristics of the business entity (size of the enterprise; influence of organizational structure; production process management structure; production technology; internal standards; staff qualifications) and industry characteristics functioning (social significance of manufactured products; short production cycle; lack of work in progress; cyclical sales; strict compliance with technology and material consumption rates; proximity to markets for finished products). It is substantiated that the accounting and analytical support is formed from the control subsystem (control over the quality, reliability, timeliness of information; control over the organization and efficiency of the subsystem of accounting and economic analysis; control over the achievement of targets); accounting (observation, measurement, systematization, generalization of accounting data), analytical (formation of the program of analytical works, estimation in dynamics, carrying out the systematic analysis, carrying out the analysis proceeding from real indicators of the financial and nonfinancial information on the basis of the generated reporting on the made organic production). The components of accounting and analytical support in terms of information support and cost management for the production of organic products are detailed. A promising area of research is the development of internal management reporting, improvement of financial and nonfinancial reporting in terms of reflecting the costs of production of organic products; detailing the control component of accounting and analytical support and the formation of methods of analysis to assess the efficiency of organic production.

Key words: organic products, organic production, accounting and analytical support, costs, reporting.

Постановка проблеми. Сучасні світові тенденції розвитку суспільства свідчать про зміни у свідомості людей. Так, «гарним тоном» тепер є масове піклування про збереження власного здоров'я, подовження років активного життя, молодості, підтримку імунітету та забезпечення довголіття. Люди активно пропагують різноманітні системи правильного та корисного харчування, вживання вітамінів, мінералів та слідкують за об'ємами спожитої чистої води. Так, мейнстримом стали здоровий спосіб життя, зниження екологічного навантаження, переробка та сортування відходів, пропагування ідей циркулярної економіки, вирощування органічної продукції тощо. Усе це є складовими частинами вектору сталого розвитку суспільства. Наведені тенденції сприяли формуванню пріоритетного напряму, яким є розвиток органічного сільськогосподарського виробництва як в Україні, так і у світі.

За кордоном розвиток виробництва органічної продукції підтримується та популяризується понад останніх тридцять років. Так, у дослідженнях “The world of agriculture. Statistics and emergingrends 2019” («Світ сільського господарства. Статистика та нові тенденції 2019»), проведених Науково-дослідним інститутом органічного землеробства (нім. Forschungsinstitut für biologischen Landbau) та IFOAM, установлено, що у 2019 р. органічному сільському господарству приділяли увагу 2,9 млн. виробників у 181 країні світу, де під органічне виробництво сертифіковано 50,9 млн. га [17].

Європейський Союз, який є другим за величиною органічним ринком, надав дані про свій органічний імпорт, вперше показуючи ключову імпортну продукцію та клю- 
чові країни-імпортери. Так, у 2018 р. СС імпортував 3,3 млн. т органічних агропродовольчих продуктів. Частка України в органічному імпорті становить 8\% (501 виробник української органічної продукції $є$ найважливішими постачальниками органічної продукції до ЄС з європейського континенту). Серед українського органічного імпорту $70 \%$ складають зернові культури, крім пшениці та рису $(42,8 \%)$, а також пшениця $(28,5 \%)$. Олійні культури становлять понад $15 \%$, а саме олійні, крім сої, складають $10,8 \%$, а соя $-5 \%$ [24].

3 огляду на таку тенденцію «виробництво органічної продукції вимагає ефективного управління як на мікро-, так і на макрорівнях, що неможливо без повної та систематичної інформаційної підтримки. В основі такої інформації перебувають дані бухгалтерського обліку, фінансової та статистичної звітності», - зауважує Я.П. Іщенко [8].

Зокрема, нині недостатньо розробленими та уніфікованими залишаються методики бухгалтерського обліку, економічного аналізу, контролю виробництва органічної продукції. Потребують уточнення склад витрат на виробництво органічної продукції та розроблення методики управління ними; не досліджені питання оперативного оцінювання ефективності виробництва органічної продукції та ступеня іiї впливу на результати діяльності підприємства загалом. Таким чином, недостатність теоретичних досліджень i практичних рекомендацій щодо формування обліково-аналітичного забезпечення виробництва органічної продукції актуалізувала вибраний напрям дослідження.

Аналіз останніх досліджень і публікацій. Питанням розвитку обліково-аналітичного забезпечення виробництва органічної продукції присвячено публікації таких науковців, як Л.С. Гангал [2], М.М. Гузь [6], І.В. Іонаш, Т.А. Мельник [7], Я.П. Іщенко [8; 9], Г.М. Пасемко [18], Н.I. Поповенко, Л.П. Сухіна [20]. Зауважимо, що напрацювання дослідників $є$ достатньо грунтовними. Проте відсутність єдиного підходу до вирішення поставленого питання дає змогу говорити про його дискусійність та окреслює площину подальших досліджень.

Формулювання цілей статті. Мета статті полягає в оцінюванні наявних підходів до обліково-аналітичного забезпечення виробництва органічної продукції та спробі їх уніфікації для формування ефективного облікового-аналітичного забезпечення.

Виклад основного матеріалу. Проаналізувавши підходи до сутності обліково-аналітичного забезпечення, наведені у дослідженнях В.І. Бережного, Г.С. Крохочова, В.В. Лесняк [1], 3.В. Удалової [22], А.Ф. Марданової [12], Я.П. Мельничук [13], Л.С. Гангал [2], С.Ф. Голова [4], Г.М. Пасемко [18] та інших науковців, можемо зробити висновок, що обліково-аналітичне забезпечення - це система взаємопов'язаних підсистем (облікової, аналітичної та контрольної), основною метою якої $є$ інформаційне забезпечення менеджменту суб'єкта господарювання на основі формування як поточної інформації, так і інформації у необхідних аналітичних розрізах, що базується як на фінансових (статистичних, податкових, облікових даних), так і на нефінансових показниках.

Для повного розкриття усіх заявлених складових частин обліково-аналітичного забезпечення органічного виробництва варто формувати окремі наукові праці, тому наше дослідження матиме оглядовий теоретичний характер.

Так, вивчення особливостей діяльності сільськогосподарських підприємств дало змогу окреслити такі специфічні особливості, які впливатимуть на організацію обліково-аналітичного забезпечення органічного виробництва, які слід враховувати:

- чітке дотримання технології процесу виробництва та дотримання норм витрат виробництва органічної продукції;

- необхідність уточнення плану виробництва 3 огляду на попит на виготовлену органічну продукцію та обсяги замовлення;

- короткий термін зберігання органічної продукції;

- врахування традицій споживання тієї чи іншої продукції у країні;

- висока конкуренція в сегменті органічного виробництва; 
- залежність сільськогосподарського підприємства від постачальників і якості сировини, що використовується для виробничих потреб;

- розвиток допоміжних та обслуговуючих виробництв (логістичні та маркетингові послуги, виробництво упаковки й тари);

- складність провадження логістичної діяльності на значні відстані через нерівномірне розміщення виробничих потужностей та короткий термін зберігання продукції;

- можливість використання органічних аграрних розписок під час операцій купівлі/постачання/розрахунків за виготовлену органічну продукцію/органічну сировину, що мінімізує ризики та зменшує потенційні витрати.

Наведені галузеві особливості та досвід досліджень низки науковців у сфері формування обліково-аналітичного забезпечення дали змогу схематично окреслити обліково-аналітичне забезпечення виробництва органічної продукції, що наведено на рис. 1.

Як зауважує Л.С. Галаган, «облікова система генерує інформацію, яка слугує підставою для прийняття поточних управлінських рішень, що дає можливість розраховувати прогнозні значення показників та визначати напрями управління об'єктами; забезпечує можливість проводити факторний аналіз зміни досліджуваних показників тощо» [2].

До такої інформації можна віднести облікові джерела інформації, а саме базові документи, що регулюють методику ведення обліку виробництва органічної продукції, первинні документи, органічну аграрну розписку, регістри аналітичного та синтетичного обліку, бухгалтерську, податкову, статистичну та нефінансову звітність, положення про облікову політику, а також позаоблікові джерела інформації, такі як офіційні нормативно-правові документи, господарсько-правові документи, інформацію про контрагентів, дані Державної служби статистики, інформацію про конкурентів.

Зупинимось на окремих складових частинах обліково-аналітичного забезпечення органічного виробництва. Одними з перших джерел інформації є первинні документи. Як зауважують Н.О. Голуб [5], І.В. Іонаш, Т.А. Мельник [7] І.В. Зумула та Д.М. Людвенко [25], формування пакета первинних бухгалтерських документів під час виробництва екологічно чистої продукції є об’ єктивною необхідністю. В основу розроблення такої інформаційної бази мають бути покладені стандарти екологічного виробництва й технологія виробництва продукції.

Наступною важливою складовою частиною обліково-аналітичного забезпечення виробництва органічної продукції є інформація про витрати виробництва, особливо 3 урахуванням специфіки досліджуваного об'єкта.

Огляд наукових праць дав змогу зробити висновок, що єдиного підходу до складу витрат на виробництво органічної продукції немає. Кожен дослідник наводить власні напрацювання. Ми можемо погодитись із кожним із них, адже, дійсно, специфіка діяльності кожного окремого сільськогосподарського виробника є особливою, тому витрати можуть не бути ідентичними.

Так, І.В. Замула та Д.М. Людвенко у своїх дослідженнях визначають витратами на органічне виробництво матеріальні витрати (сировина та матеріали, що використовуються в процесі органічного виробництва: обробіток грунту, захист рослин; внесення добрив; органічні кормові матеріали; посіви тощо; пакувальні матеріали, придатні для органічних продуктів), трудові та соціальні внески (виплати працівникам в органічному секторі; нарахування ССВ; витрати на підвищення кваліфікації робітників (у галузі органічного виробництва); премії для працівників органічного сектору; надання соціальних пакетів для працівників органічного виробництва), знос для необоротних активів, що використовуються в процесі органічного виробництва, інші витрати (витрати на сертифікацію; витрати на управління, такі як участь у семінарах, пов'язаних з органічним виробництвом; витрати на дотримання вимог органічного виробництва; витрати на зберігання; інші витрати) [25]. 


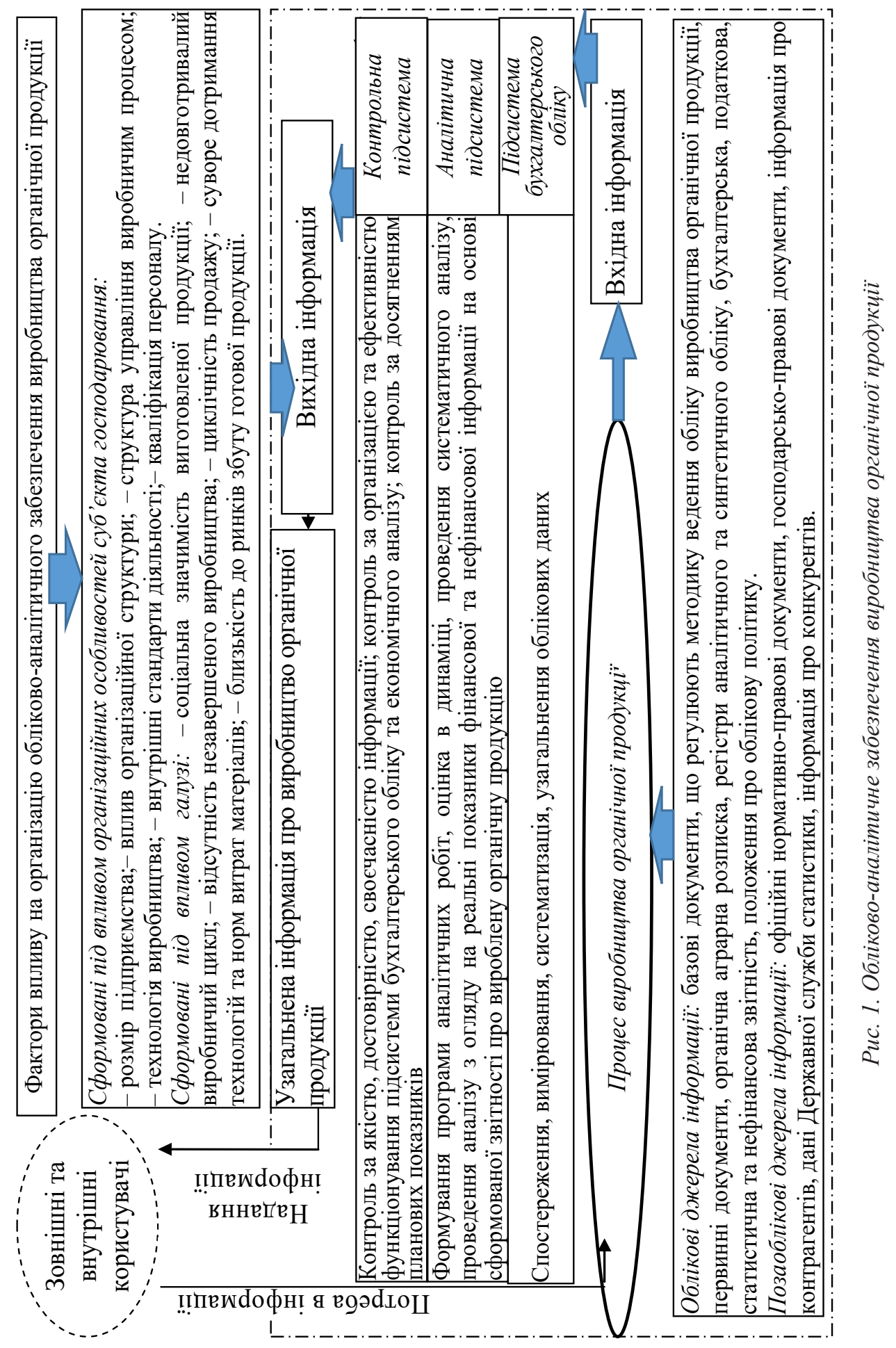


Я.П. Іщенко до витрат на органічне виробництво включає витрати на оплату праці; насіння та посадковий матеріал; паливо та мастильні матеріали; добрива; засоби захисту рослин та тварин; корми; сировину та матеріали; роботи та послуги; ремонт необоротних активів; інші витрати на утримання основних засобів; загальновиробничі [9; 21].

Проте єдиною має бути система облікового відображення таких витрат. Так, за останні десятиліття з'явилися абсолютно нові методи обліку витрат і системи калькулювання собівартості, розроблення і впровадження яких активно ведеться в таких постіндустріальних країнах, як США, Японія, Німеччина, Франція, інші країни Західної Європи. Особливістю зарубіжної практики обліку є той факт, що системи калькулювання тісно взаємопов'язані з концепціями (моделями) управління підприємством, тобто під конкретний метод управління розробляється система обліку [16, с. 104].

Визнані у всьому світі системи управління та обліку витрат виробництва наведено в табл. 1.

Перша група методів орієнтована на виробництво, оскільки система бухгалтерського обліку формується на базі визначеної концепції виробництва та управління, тісно пов'язана з виробничими процесами [23, с. 29-30].

Друга група методів, орієнтованих на облік, розглядає підприємство як набір взаємозалежних видів діяльності (функцій, операцій), у процесі яких споживаються різні ресурси (матеріали, праця, устаткування). Відмінність полягає в тому, що в АВС під час розподілу витрат для кожного виду діяльності передбачений свій носій витрат, а у TD ABC використовується лише драйвер часу.

Третя група методів визначає чітко структуровану та детальну концепцію управління витратами за допомогою нормативного обліку витрат і гнучкого планування бюджетів. Ці методи об'єднують такі основні принципи:

- центри відповідальності (калькулювання) є головними суб'єктами планування, обліку витрат і собівартості продукції; така розстановка акцентів дає змогу керівництву підприємств здійснювати управління центрами відповідальності і контроль їх продуктивності [10, с. 47];

- чітке розмежування постійних і змінних витрат у кожному окремому центрі калькулювання.

Невід'ємною передумовою застосування прогресивних методів обліку витрат є комп’ютеризація, що дає змогу значно прискорити швидкість здійснення зворотного зв'язку (система звітності в режимі реального часу), розширює можливості оброблення зібраної в системі бухгалтерського обліку інформації для прогнозування, прийняття рішень, ефективного контролю за витратами, комплексного оцінювання та аналізу витрат. Без належного рівня технічного забезпечення важко отримати вагомі практичні результати від застосування новітніх методів обліку витрат. Хоча не можна не відзначити, що програмні продукти є лише інструментом для роботи з інформацією. Ефективність його використання визначається не лише якістю самого продукту, але й розумінням користувачами методології бухгалтерського обліку витрат загалом i закладеної в програмний продукт зокрема.

Таким чином, організація бухгалтерського обліку виробничих витрат на підприємстві має забезпечувати ефективність і дієвість всієї системи управління, зокрема давати можливість оперативно отримувати достовірну та повну облікову інформацію про витрати виробництва, своєчасно приймати необхідні управлінські рішення задля забезпечення раціонального використання виробничих ресурсів. Організація такої системи вимагає особливого підходу до вибору основних елементів і напрямів організації бухгалтерського обліку як у сфері методології, так і у сфері кадрового та технічного забезпечення. Це поліпшить інформаційне забезпечення контрольної функції управління щодо здійснення органічного виробництва та забезпечить можливість обгрунтованого калькулювання собівартості продукції. 
可

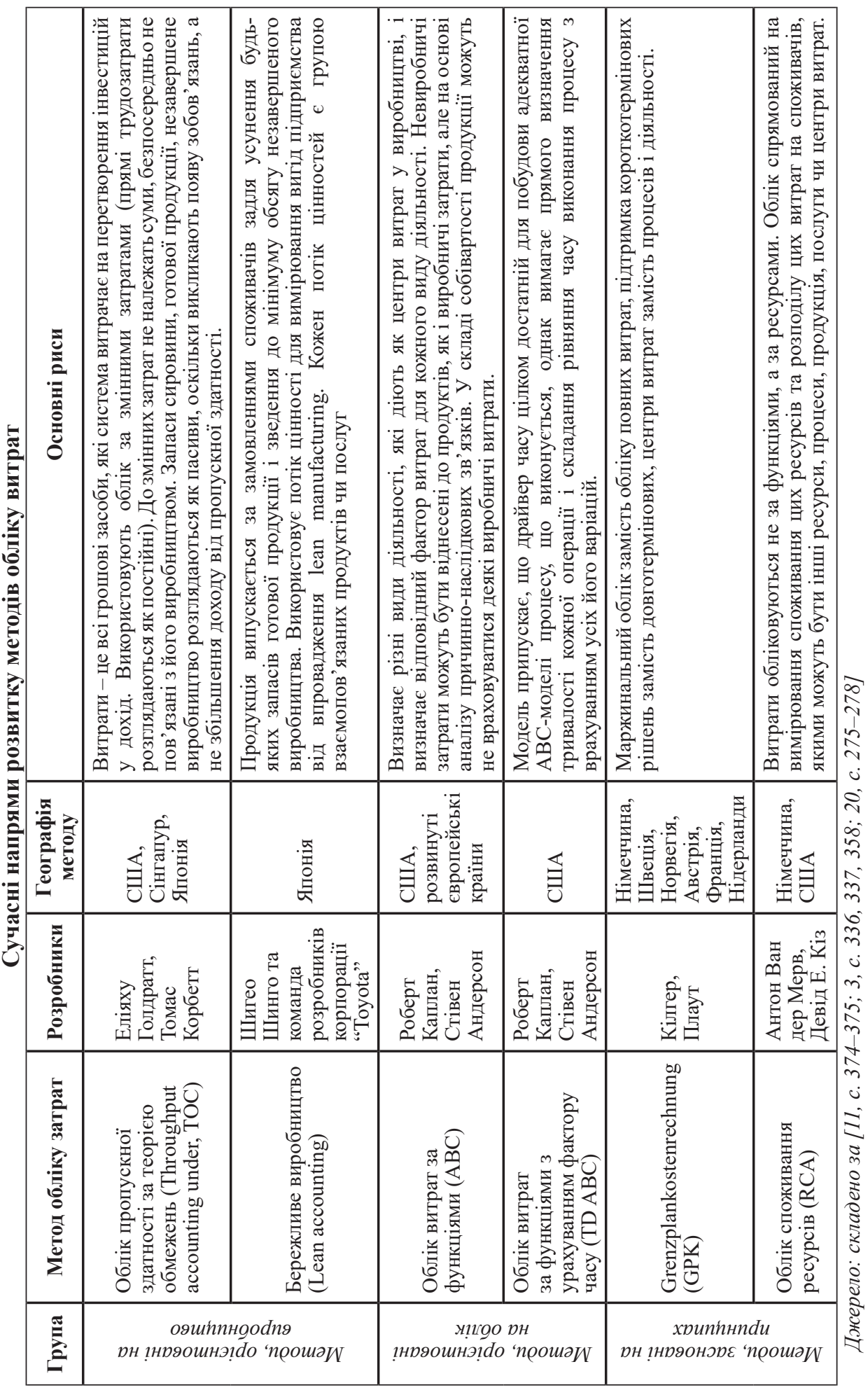


Висновки. Таким чином, проведені дослідження дали змогу актуалізувати важливість наукового пошуку у сфері розроблення обліково-аналітичного забезпечення виробництва органічної продукції. На основі проаналізованих наукових праць запропоновано власний підхід до обліково-аналітичного забезпечення виробництва органічної продукції, що формується під впливом організаційних особливостей суб'єкта господарювання та особливостей галузі функціонування. Деталізовано складові частини обліково-аналітичного забезпечення щодо інформаційного забезпечення та управління витратами на виробництво органічної продукції. Перспективними напрямами дослідження $є$ розроблення внутрішньої управлінської звітності, удосконалення фінансової та нефінансової звітності щодо відображення витрат на виробництво органічної продукції, деталізація контрольної складової частини обліково-аналітичного забезпечення та формування методики аналізу оцінювання ефективності виробництва органічної продукції.

\section{Список використаних джерел:}

1. Бережной В.И., Крохочева Г.Е., Лесняк В.В. Бухгалтерский управленческий учет : учебное пособие. Москва : НИЦ ИНФРА, 2014. 176 с.

2. Гангал Л.С. Механізм обліково-аналітичного забезпечення управління конкурентоспроможністю сільськогосподарських підприємств. Інноваційна економіка. 2016. № 1-2. С. 124-130.

3. Гаррисон Р., Норин Э., Брюэр П. Управленческий учет / пер. с англ. под ред. М.А. Карлика. 12-е изд. Санкт-Петербург : Питер, 2010. 592 с.

4. Голов С.Ф. Управлінський облік : підручник. Київ : Лібра, 2003. 704 с.

5. Голуб Н.О. Облік екологічно чистої продукції. URL: http://ic.faaf.org.ua/pdf/62-oblikekologichno-chistoi-produkcii.pdf (дата звернення: 20.12.2020).

6. Гузь М.М. Інформаційно-аналітичне забезпечення управління розвитком органічного сільського господарства. Науковий вісник Наиіонального університету біоресурсів і природокористування України. Серія: Економіка, аграрний менеджмент, бізнес. 2018. Вип. 290. C. $72-79$.

7. Іонаш І.В., Мельник Т.А Посилення обліково-інформаційного забезпечення управління - запорука ефективного розвитку органічного виробництва. Молодий вчений. 2014. № 6 (09). C. $133-135$.

8. Іщенко Я.П. Облік витрат та виходу органічної сільськогосподарської продукції рослинництва. Інститут бухгалтерського обліку, контроль та аналіз в умовах глобалізації. 2019. Вип. 3-4. С. 26-36. DOI: https://doi.org/10.35774/ibo2019.03.026.

9. Іщенко Я.П. Особливості організації обліку витрат органічного сільськогосподарського виробництва. Економіка. Фінанси. Менеджмент: актуальні питання науки і практики. 2019. № 7. С. $122-132$.

10. Каплан Р., Купер Р. Функционально-стоимостной анализ: практическое применение. Москва : Williams, 2007. 352 c.

11. Карельская С.Н. Прогнозирование в бухгалтерском учете. Соколовские чтения «Взгляд из прошлого в будущее» : доклады международной научной конференции (10-11 февраля 2010 г.). Т. 1. Санкт-Петербург : Нестор-История, 2011. 472 с.

12. Марданова А.Ф. Развитие учетно-аналитического обеспечения производства продукции растениеводства : автореф. дисс. ... канд. экон. наук : спец. 08.00.12 [Место защиты: Самарский государственный экономический университет]. Самара, 2013. 24 с.

13. Мельничук Я.П. Облікова політика щодо виробництва та реалізації органічної продукції. Теорія і практика економіки та управління промисловими підприємствами. 2016. № 3 (25). C. 86-92.

14. Методичні рекомендації з планування, обліку і калькулювання собівартості продукції (робіт послуг) сільськогосподарських підприємств : Наказ Міністерства аграрної політики України від 18 травня 2001 р. № 132. URL: https://zakon.rada.gov.ua/rada/show/v0132555-01 (дата звернення: 20.12.2020).

15. Мороз Ю.Ю, Цаль-Цалко Ю.С. Облікове забезпечення господарської діяльності товаровиробників органічної продукції. URL: http://ir.znau.edu.ua/bitstream/123456789/8415/1/ Organik_2017_289-297.pdf (дата звернення: 20.12.2020). 
16. Непогодина Н.И., Цурган М.С. Актуальные вопросы внедрения зарубежного опыта учета затрат при определении себестоимости продукции. Вісник СевНТУ. Серія: Економіка і фінанcu. 2010. № 109. С. 103-107.

17. Орешникова О.В., Король А.Г. Органическое производство как фактор развития экологичного сельского хозяйства в Беларуси. Модернизация экономики Беларуси: проблемь и пути ux решения : материалы международной научной конференции, посвященной 50-летию экономического факультета Гомельского государственного университета им. Ф. Скорины (Гомель, 18 октября 2019 г.). Гомель : ГГУ им. Ф. Скорины, 2019. С. 223-224 URL: https://rep.polessu.by/ bitstream/123456789/17016/1/Oreshnikova_OV Korol\%27 AG Organicheskoe proizvodstvo $\% 20$ kak\%20faktor\%20razvitiia\%20ekologichnogo \%20sel\%skogo\%20khoziaistva $\% 20 \mathrm{v} \% 20 \mathrm{Belarusi}$.pdf (дата звернення: 20.12.2020).

18. Пасемко Г.М. Обліково-аналітичне забезпечення управління ведення органічного сільськогосподарського виробництва. Вісник ЖНАЕУ. 2016. № 1 (54). Т. 2. С. 190-197.

19. Подолянчук О.А. Сутність та основи обліку органічної продукції. Агросвіт. 2019. № 16. С. 51-57. DOI: 10.32702/2306-6792.2019.16.51.

20. Поповенко Н.И., Сухина Л.П. Основные финансовые и учетные аспекты теории ограничения систем Э. Голдратта. Вісник Хмельницького національного університету. 2009. № 4 (т. 2). С. 275-278.

21. Про основні принципи та вимоги до органічного виробництва, обігу та маркування органічної продукції : Закон України від 10 липня 2018 р. № 2496-VIII. URL: https://zakon.rada.gov.ua/ laws/show/2496-19 (дата звернення: 20.12.2020).

22. Удалова 3.В. Методологические основы формирования учетно-аналитического обеспечения управления сельськохозяйственными организацыями. Аудит и финансовый анализ. № 5. 2010. URL: https://auditfin.com/fin/2010/5/09_06.pdf (дата звернення: 20.12.2020).

23. Adkins T. Case studies in performance management: a guide from the experts. New Jersey : John Wiley \& Sons, Inc., 2006. 238 p.

24. Willer H., Schlatter B., Trávníček J., Kemper L., Lernoud J. The World of Organic Agriculture Statistics and Emerging Trends 2020. URL: https://orgprints.org/37222/9/willer-et-al-2020-full-document-2020-02-28-4th-corrigenda.pdf (дата звернення: 20.12.2020).

25. Zamula I., Liudvenko D. Information support and development of organic production Green, Blue \& Digital Economy Journal. 2020. Vol. 1. No. 2. P. 1-7.

\section{References:}

1. Berezhnoj V.I., Krohocheva G.E., Lesnyak V.V. (2014) Buhgalterskij upravlencheskij uchet [Management Accounting: A Textbook]. Moscow: NIC INFRA. (in Russian)

2. Gangal L.S. (2016) Mekhanizm oblikovo-analitichnogo zabezpechennya upravlinnya konkurentospromozhnistyu sil's'kogospodars'kih pidpriemstv [Mechanism of accounting and analytical support for managing the competitiveness of agricultural enterprises]. Innovacijna ekonomika, no. $1-2$, pp. 124-130.

3. Garrison R. (2010) Upravlencheskij uchet [Management accounting]. Saint-Petersburg: Piter. (in Russian)

4. Golov S.F. (2003) Upravlins'kij oblik [Management accounting]. Kyiv: Libra. (in Ukrainian)

5. Golub N.O. Oblik ekologichno chistoï produkciï [Accounting for environmentally friendly products]. URL: http://ic.faaf.org.ua/pdf/62-oblik-ekologichno-chistoi-produkcii.pdf (accessed 20 December 2020).

6. Guz' M.M. (2018) Informacijno-analitichne zabezpechennya upravlinnya rozvitkom organichnogo sil's'kogo gospodarstva [Information and analytical support for the management of organic agriculture]. Naukovij visnik Nacional'nogo universitetu bioresursiv i prirodokoristuvannya Ukrajni. Seriya: Ekonomika, agrarnij menedzhment, biznes. vol. 290, pp. 72-79.

7. Ionash I.V., Mel'nik T.A (2014) Posilennya oblikovo-informacijnogo zabezpechennya upravlinnya - zaporuka efektivnogo rozvitku organichnogo virobnictva [Strengthening accounting and information management - the key to effective development of organic production]. Molodij vchenij, no. 6 (09), pp. 133-135.

8. Ishchenko Ya.P. (2019) Oblik vitrat ta vihodu organichnoï sil's'kogospodars'koï produkciï roslinnictva [Accounting for costs and yield of organic agricultural products of crop production]. Institut buh- 
galters 'kogo obliku, kontrol' ta analiz v umovah globalizaciï. vol. 3-4, pp. 26-36. DOI: https://doi.org/ 10.35774/ibo2019.03.026.

9. Ishchenko Ya.P. (2019) Osoblivosti organizaciï obliku vitrat organichnogo sil's'kogospodars'kogo virobnictva [Features of the organization of the account of expenses of organic agricultural production]. Ekonomika. Finansi. Menedzhment: aktual'ni pitannya nauki i praktiki. no. 7, pp. $122-132$.

10. Kaplan R., Kuper R. (2007) Funkcional'no-stoimostnoj analiz: prakticheskoe primenenie [Functional cost analysis: practical application]. Moscow: Williams. (in Russian)

11. Karel'skaya S.N. (2010) Prognozirovanie v buhgalterskom uchete [Forecasting in accounting]. Proceedings of the Sokolovskie chteniya "Vzglyad iz proshlogo v budushchee": doklady mezhdunarodnoj nauchnoj konferencii (Russia, Saint-Petersburg, 10-11 February 2010). Saint-Petersburg: Nestor-Istoriya. (in Russian)

12. Mardanova A.F. (2013) Razvitie uchetno-analiticheskogo obespecheniya proizvodstva produkcii rastenievodstva [Development of accounting and analytical support for crop production] (PhD Thesis), Samara.

13. Mel'nichuk Ya.P. (2016) Oblikova politika shchodo virobnictva ta realizaciï organichnoï produkcii [Accounting policy for the production and sale of organic products]. Teoriya i praktika ekonomiki ta upravlinnya promislovimi pidpriemstvami, no. 3 (25), pp. 86-92.

14. Metodichni rekomendaciï z planuvannya, obliku i kal'kulyuvannya sobivartosti produkciï (robit poslug) sil's'kogospodars'kih pidpriemstv [Methodical recommendations on planning, accounting and calculation of the cost of products (works of services) of agricultural enterprises]: Nakaz Ministerstva agrarnoï politiki Ukraïni vid 18.05.2001 № 132. Available at: https://zakon.rada.gov.ua/ rada/show/v0132555-01 (accessed 20 December 2020).

15. Moroz Yu.Yu (2017), Cal'-Calko Yu.S. Oblikove zabezpechennya gospodars'koj diyal'nosti tovarovirobnikiv organichnoj produkciï [Accounting support of economic activity of commodity producers of organic products]. Available at: http://ir.znau.edu.ua/bitstream/123456789/8415/1/Organik_2017_289-297.pdf (accessed 20 December 2020).

16. Nepogodina N.I., Curgan M.S. (2010) Aktual'nye voprosy vnedreniya zarubezhnogo opyta ucheta zatrat pri opredelenii sebestoimosti produkcii [Topical issues of introduction of foreign experience in cost accounting in determining the cost of production]. Visnik SevNTU. Seriya: Ekonomika i finansi, no. 109, pp. 103-107.

17. Oreshnikova O.V., Korol' A.G. (2019) Organicheskoe proizvodstvo kak faktor razvitiya ekologichnogo sel'skogo hozyajstva $v$ Belarusi [Organic production as a factor in the development of organic agriculture in Belarus]. Modernizaciya ekonomiki Belarusi: problemy i puti ih resheniya [Elektronnyj resurs]: mezhdunar. nauch. konf., posvyashch. 50-letiyu ekon. fak-ta Gomel'skogo gos. un-ta im. F. Skoriny (Gomel', 18 okt. 2019 g.). Gomel’: GGU im. F. Skoriny. P. 223-224. Available at: https://rep.polessu.by/bitstream/123456789/17016/1/Oreshnikova_OV_Korol\%27_AG_Organicheskoe_proizvodstvo $\% 20 \mathrm{kak} \% 20$ faktor\%20razvitiia\%20 kologichnogo $\% 20 \mathrm{sel} \% 27 \mathrm{skogo} \% 20 \mathrm{khozi}$ aistva\%20v\%20Belarusi.pdf (accessed 20 December 2020).

18. Pasemko G.M. (2016) Oblikovo-analitichne zabezpechennya upravlinnya vedennya organichnogo sil's'kogospodars'kogo virobnictva [Accounting and analytical management of organic agricultural production]. Visnik ZHNAEU, no. 1 (54), t. 2, pp. 190-197.

19. Podolyanchuk O.A. (2019) Sutnist' ta osnovi obliku organichnoï produkciï [The essence and basics of accounting for organic products]. Agrosvit, no. 16, pp. 51-57. DOI: 10.32702/2306-6792. 2019.16.51.

20. Popovenko N.I., Suhina L.P. (2009) Osnovnye finansovye i uchetnye aspekty teorii ogranicheniya sistem [The main financial and accounting aspects of the theory of constraints of E. Goldratt's systems]. Visnik Hmel'nic'kogo nacional'nogo universitetu, no. 4 (t. 2), pp. 275-278.

21. Pro osnovni principi ta vimogi do organichnogo virobnictva, obigu ta markuvannya organichnoï produkcij [On the basic principles and requirements for organic production, circulation and labeling of organic products]: Zakon Ukrajni vid 10.07.2018 r. № 2496-VIII. Available at: https://zakon.rada.gov.ua/laws/show/2496-19 (accessed 20 December 2020.

22. Udalova Z.V. (2010) Metodologicheskie osnovy formirovaniya uchetno-analiticheskogo obespecheniya upravleniya sel's'kohozyajstvennymi organizacyyami [Methodological bases of formation of accounting and analytical support of management of the agricultural organizations]. Audit y finansovyj analiz, no. 5. Available at: https://auditfin.com/fin/2010/5/09_06.pdf (accessed 20 December 2020). 
23. Adkins T. (2006) Case studies in performance management: a guide from the experts. New Jersey: John Wiley \& Sons, Inc., 238 p.

24. Willer Helga, Schlatter Bernhard, Trávníček Jan, Kemper Laura, Lernoud Julia (2020) The World of Organic Agriculture Statistics and Emerging Trends. Available at: https://orgprints.org/ 37222/9/willer-et-al-2020-full-document-2020-02-28-4th-corrigenda.pdf (accessed 20 December 2020).

25. Zamula Iryna, Liudvenko Dmytro (2020) Information support and development of organic production Green. Blue \& Digital Economy Journal, vol. 1, no. 2, pp. 1-7. 